Zeller, ${ }^{1}$ this description being based on specimens from Colombia, S. A. In this country it was described by Hulst in 1887 in Entomologica Americana (v. 3 p. 137) as Stenoptycha pallulella.

The original description of the genus was given by Heinemann under the name Stenoptycha, in $\mathrm{I} 865$, in his work on the lepidoptera of Germany and Switzerland, ${ }^{2}$ but as this generic name

1 Hor. Soc. ent. ross., 1882, v. 16, p. 224 .

2 Die schmetterlinge Deutschlands und der Schweiz, I 865, p. 190 . was preoccupied by Zeller, ${ }^{1}$ the genus was rechristened Melia by Heineman, on a later page of the same work. ${ }^{2}$ Melia proved, however, also to be preoccupied ${ }^{8}$ as noted by Zeller in $\mathrm{r} 867$, and the current Euzophera was then finally proposed.

1 Entom. zeitung Stettin, 1863, p. 154. Zeller's use, of this name for a genus of pterophoridae is also illegitimate, as it has already been applied by Agassiz to a Medusa (Contr. nat. hist. United States, I862, v. 2,p. 149)

2 l.c., p. 209.

3 Used previously in muscidae, pyralidae, crustacea, mollusca and botany.

4 Entom. zeitung Stettin, 1867. p. 377 .

\title{
DESCRIPTIONS OF SOME NEW NORTH AMERICAN MOTHS.
}

BY WILLIAM BEUTENMÜLILR, NEW YORK.

\section{Datana modesta, n. sp.}

Head and thoracic patch yellowish ochreous, remaining parts of thorax rusty brown. Primaries rusty brown with a small, elongated, discal spot on the middle of the wing and another smaller spot before the middle. About the apical fourth of the wing is an illdefined, transverse, curved band a little darker than the ground color. Beyond this band the wing assumes a purplish brownish color. Secondaries much paler than the primaries. Body above yellowish ochreous, beneath pale ochreous. Secondaries beneath pale ochreous, primaries somewhat darker. Expanse $48 \mathrm{~mm}$. I 8 . Hab. Kissimmee, Florida, May, Type Collection, Chas. Palm.
Allied to D. foridana, but differing from it by having the thoracic patch yellowish ochreous, and by the absence of the two additional transverse bands.

$$
\text { Datana PALMiI, n. sp. }
$$

Head and thoracic patch deep velvety brown, remaining parts of thorax cinnamon brown, mixed with whitish scales. Primaries cinnamon brown (in one specimen nearly as deep in color as $D$. angusii) and thickly covered with whitish scales so as to nearly obscure the ground color. Across the wing are four narrow, transverse bands same as the ground color. The first on the basal fourth, oblique; the second a little before the middle slightly curved; the third a little beyond the middle and 
the fourth on the apical fourth, both these bands are curved outwardly. Secondaries pale cinnamon brown. Primaries beneath same color as the secondaries above. Secondaries beneath ochreous. Expanse $48 \mathrm{~mm} .4$ $\delta$ o . Hab. Delaware Water Gap. Penn. June. Collected by Chas. Palm to whom I gratefully dedicate this odd species.

Allied to $D$. integerrima, from which it can be distinguished by the absence of the two discal spots, different position of the bands and also by the different color.

Both the foregoing species were compared with the types of allied species.

\section{Orgyia inornata, n. sp.}

$\delta$ Body above and below fuscous, pectinations of antennae blackish, stalk grayish. Primaries uniformly fuscous with a curved, transverse band beyond the middle, bending inwardly as it reaches the inner margin. Secondaries fuscous. Wings beneath somewhat paler than above. Expanse $15 \mathrm{~mm}$.

9. Wholly dirty whitish above and below. Length $16 \mathrm{~mm}$. Width $7 \mathrm{~mm}$.

I $\delta$. 2 9 . Collection W. Beutenmüller. Hab. Enterprise, Fla. May.

Differ from all its congeners by the

Entomological Society of London. - At the meeting of the Entomological society of London held 7 August I889. Dr. C. V. Riley was elected an honorary fellow in place of the late Dr. V. Signoret. The number of honorary fellows is limited to ten, and less than forty of the most celebrated entomolo. gists in the world have been thus honored. Dr. H. A. Hagen was elected in 1863 , Dr. J. absence of the ante-apical white spot near the inner angle, and by its plain coloration.

Larva. - Head and cervical shield bright coral red. Body above mouse color with three rows orange tubercles along each side. Each tubercle provided with a bunch of long, silvery gray hairs. Along the subdorsal region of the second, third, ninth, tenth, eleventh and twelfth segments is also a row of orange tubercles with silvery gray hair while on the dorsum of the fourth, fifth, sixth and seventh segment is a thick bunch of white hairs and from the eighth segment to the end of the body there is a broad, black stripe, with three small orange spots on each segment. On each side of the anterior parts of the first segment is a long, black pencil and one on the eleventh segment which is brown at the base. A few brown hairs are also scattered here and there over the body. Underside yellowish green. Length about $30 \mathrm{~mm}$.

Food-Plants. Live oak (2uercus virens), and cypress (Cupressus).

Cocoon.-Similar to that of O. leucostigma light brown, oval, composed of fine silk, interwoven with the hair of the larva. Length $25 \mathrm{~mm}$. Width I $2 \mathrm{~mm}$.

L. Leconte in the same year and Dr. A. S. Packard in 1884 .

Classified according to the land of their birth there are but two Americans, Drs. Leconte and Packard.

Prof. C. H. Fernald was elected a fellow at the meeting held 4 September 1889.

No. 160-164 were issued 2 Jan. I89o. 

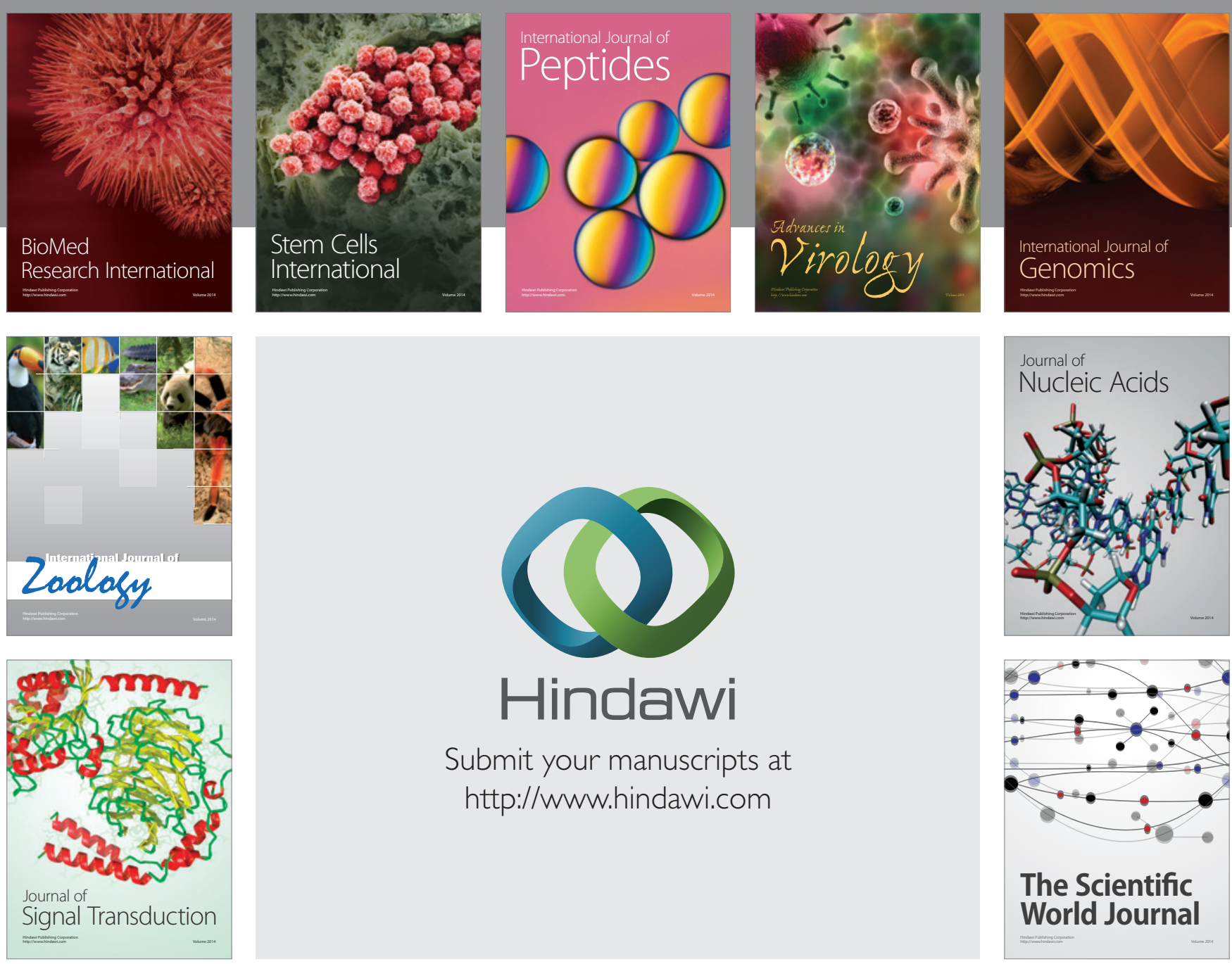

Submit your manuscripts at

http://www.hindawi.com
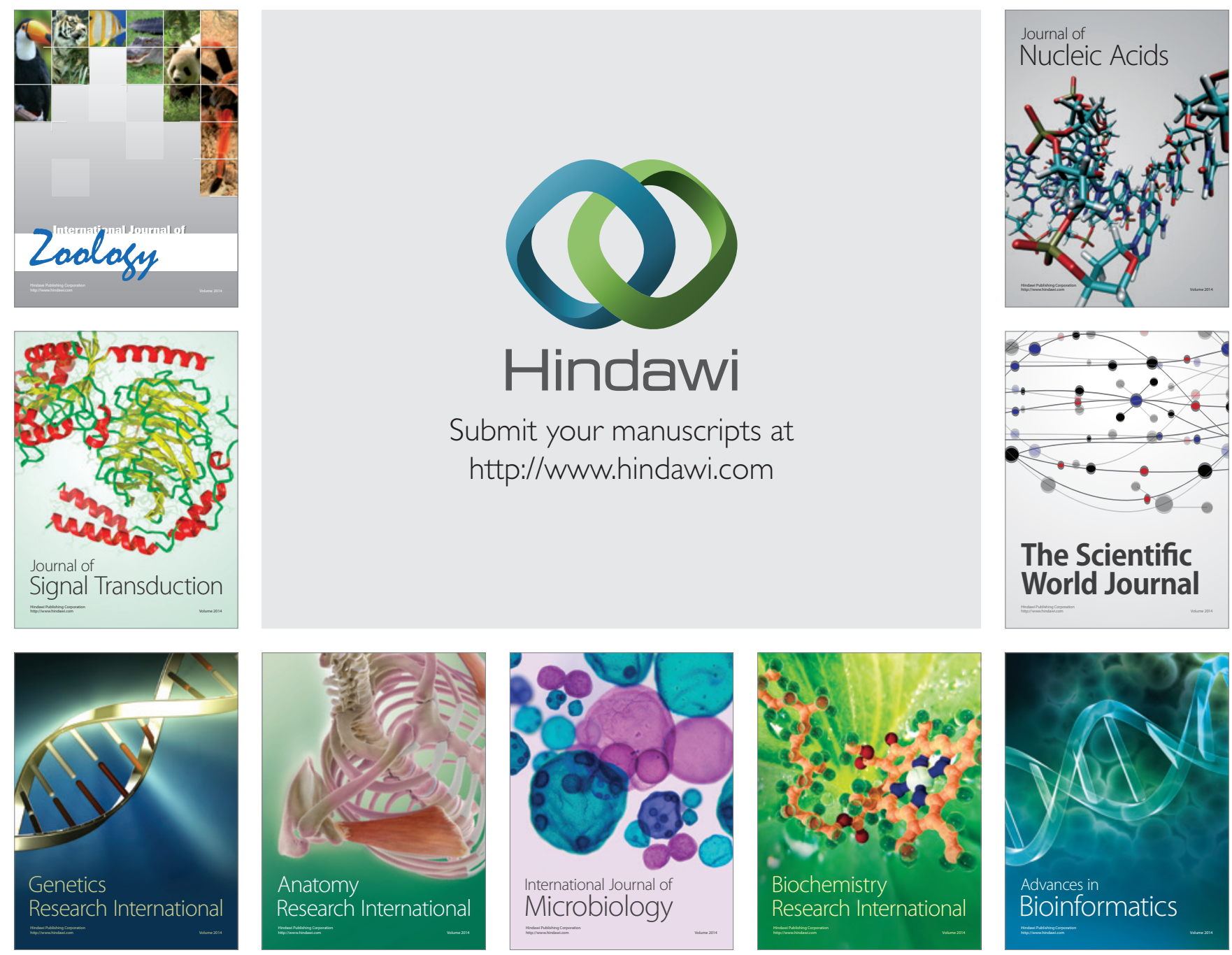

The Scientific World Journal
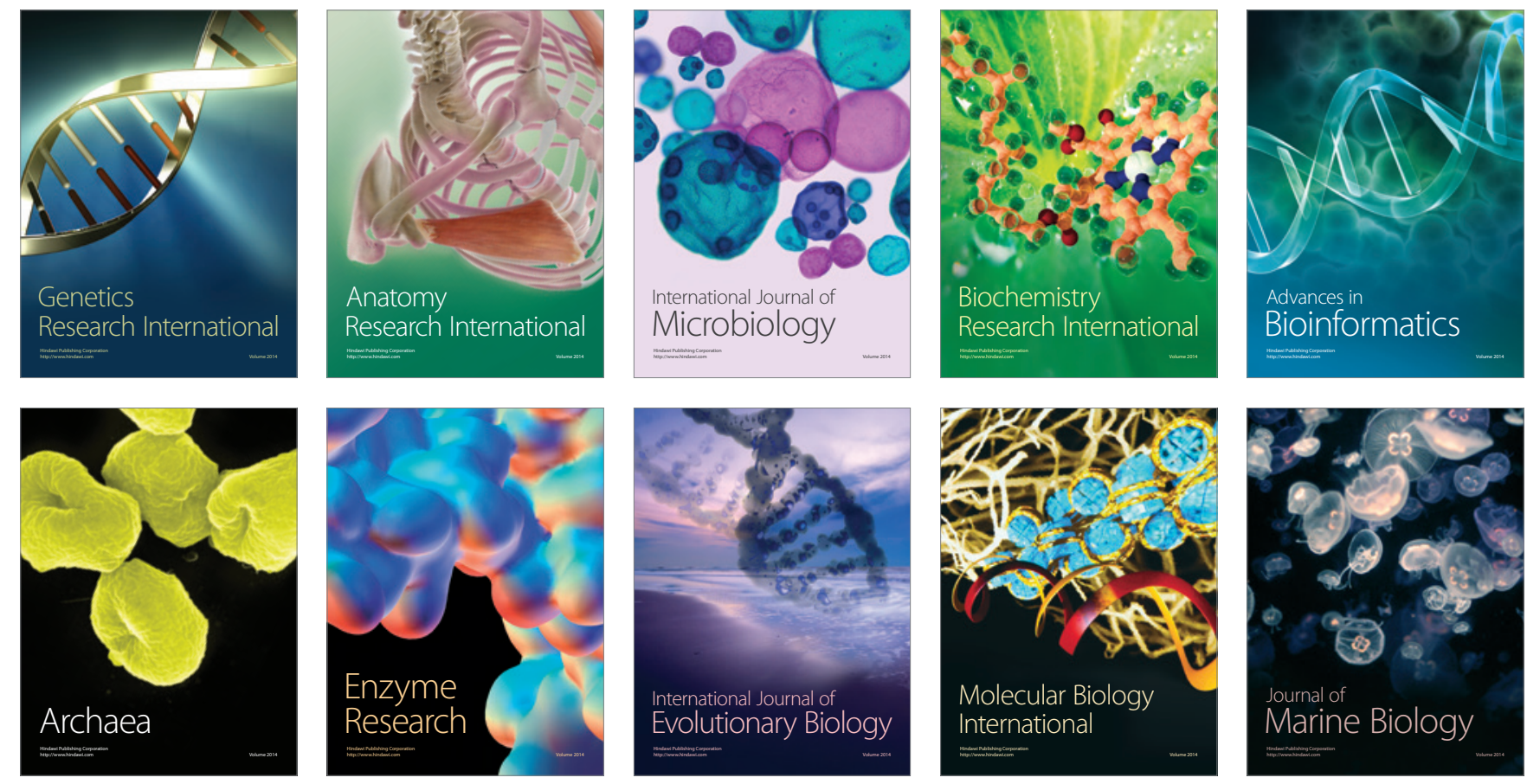